\title{
Model Pembelajaran APPOSITE Berbantuan Video Animasi dalam Meningkatkan Hasil Belajar dan Kemampuan Berpikir Tingkat Tinggi Siswa pada Materi Fluida Statis
}

\author{
Aprillia Kartika Agit Wuragil ${ }^{1 *}$, Sri Handono Budi Prastowo ${ }^{2}$ dan Maryani ${ }^{3}$ \\ 1,2,3 Pendidikan Fisika Fakultas Keguruan dan IImu Pendidikan, Universitas Jember \\ Jl. Kalimantan No. 37, Krajan Timur, Sumbersari, Kec. Sumbersari, Kabupaten Jember, Jawa Timur 68121 \\ *E-mail: wuragilagit5@gmail.com
}

\begin{abstract}
Abstrak
Penelitian dengan model pembelajaran APPOSITE (Application of Step Instruction and Elaboration) berbantuan video animasi yang memiliki tujuan mengetahui peningkatan hasil belajar dan berpikir tingkat tinggi siswa sub materi fluida statis. Penelitian jenis Pre-eksperimen desain One Group Pretes-Posttes Design. Subjek penelitian ialah siswa kelas XI MIPA 6 SMA Negeri 1 Pesanggaran Kabupaten Banyuwangi, dengan menggunakan satu kelas eksperimen yang telah ditetapkan guru mata pelajaran. Teknik perolehan data dengan menggunakan wawancara, Dokumentasi, pretes, penilaian LKS, dan post-tes. Kemampuann berpikir tingkat tinggi pada penelitian di analisis menggunakan deskriptif kuantitatif, uji t tes untuk mengetahui peningkatan hasil belajar menggunakan model APPOSITE berbantuan video animasi. Kemudian didukung oleh hasil perhitungan $\mathrm{n}$-gain nilai pretes-post-tes kelas eksperimen. Berdasarkan hasil, Model Pembelajaran APPOSITE berbantuan video animasi memiliki pengaruh baik dan keterampilan berpikir tingkat tinggi siswa dapat meningkat, model dikatakan cukup efektif meningkatkan hasil belajar. Hal ini didukung dari perhitungan n-gain yang nilai didapatkan 0,639.
\end{abstract}

Kata kunci: Model APPOSITE, Video Animasi, Peningkatan hasil belajar, berpikir tingkat tinggi

\begin{abstract}
Application of learning model APPOSITE (Application of Step Instruction and Elaboration) with animation videos on this research have to purpose a differents enhancement study result and higher order thinking skill (HOTS) student on fluida statis. Research types is pre-experiment with one group pretes-posttes design. research subject is XI MIPA 6 Student of senior high school 1 Pesanggaran Banyuwangi, with one class experiment which choosed by Fisika's teacher. Acquisition technique data is interview, documentation, pretes, student worksheet, and posttes. Analysis technique data research is use descriptive analysis to know higher order thinking skill, $t$-test to know enhancement study result of APPOSITE model with videos animation. Subsequently supported with account $n$-gain from pretes-posttes score experiment class. Based on result this research, APPOSITE learning model with animation video have a good effect and enhancement higher order thinking skill (HOTS) student, and model is effective enough to enhancement study result student. This is also supported of the result $n$-gain is obtained 0,639.
\end{abstract}

Keywords: Learning model APPOSITE, Animation Videos, enhancement student learning, HOTS

\section{PENDAHULUAN}

Fisika salah satu cabang IImu pengetahuan alam yang mendasari terbentuknya proses yang berarti sebuah prosedur untuk menekankan sebuah fakta, konsep, prinsip, teori maupun hukum. Konsep yang ada pada fisika memiliki dasar atas mengkelompokkan beberapa hal penyajian non-verbal yang pada akhirnya memiliki kecenderungan abstrak yang perlu adanya kemampuan untuk menggambarkannya (Hanna et al., 2016). Proses pembelajaran memiliki keterkaitan dengan pengangkutan konsep, keterampilan dan nilai antara guru dengan siswa (Prastowo, 2019b). Hasil belajar fisika siswa yang rendah disebabkan factor diantaranya : materi pada buku yang dirasakan terlalu bersifat teori untuk dipahami, masih 
kurang efektif pada media belajar, media pembelajaran yang digunakan dan dipilih guru tidak tepat, ketidakoptimalan siswa untuk terlibat oleh suatu proses pembelajaran dan keaktifan kelas yang banyak didominasi oleh guru atau pendidik (Supardi et al., 2015). Pembaruan pembelajaran pada kurikulum 2013 memandang perlu adanya keterampilan berpikir tingkat tinggi agar tujuan dari pencapaian pembelajaran kurikulum tersebut berjalan (Assessment, 2016)

Berdasarkan informasi di khalayak siswa SMA Pembelajaran fisika dianggap sulit oleh mereka dikarenakan kurangnya proses pemahaman konsep yang diajarkan. Pemahaman sulit yang didapatkan siswa SMA terjadi pada materi Fluida Statis saat menelaah terjadinya gejala terapung dan tenggelam, siswa menganggap bahwa sebuah benda tenggelam disebabkan adanya berat pada benda tersebut (Akmala et al., 2016).

Siswa SMA dikatakan mampu menangani masalah jika siswa dapat menelaah masalah dengan menggabungkan pengetahuannya pada situasi baru. Kemampuan ini dapat dikenal dengan keterampilan High Order Thingking Skills. Keterampilan yang menjadikan siswa mampu menghubungkan, memanipulasi serta mengubah pengetahuan dengan pengalaman yang dimiliki secara kritis dan kreatif dalam menentukan keputusan menyelesaikan masalah. Anderson dan Krathwohl mengambil beberapa ranah berpikir dari Bloom dengan kategorinya terdiri dari menganalisis, mengevaluasi, dan mencipta/mengkreasi (Romli \& Agustiawan, 2020)

Strategi penggunaan model pembelajaran APPOSITE yang penerapannya menggunakan instruksi bertahap (step instruction) dalam bentuk elaborasi. Fase elaborasi dilakukan agar adanya sebuah pengembangan, pendalaman, dan penerapan konsep yang telah dipahami siswa (Prastowo, 2019a). Penggunaan step instruction dimaksudkan ialah tahapan berupa pertanyaan yang dapat mendorong siswa menjawab pertanyaan dari permasalahan yang secara bertahap yang dapat menuju penyelesaian utama permasalahan serta melatih siswa untuk berpikir tingkat tinggi. Dalam model pembelajaran APPOSITE guru menjadi fasilitator dimana menyiapkan sebuah instruksi bertahap (step instruction) agar proses pembelajaran siswa yang tercapai (Kamila et al., 2020).

Perkembangan teknologi yang semakin pesat pada Generasi Z (1995-2010) memungkinkan siswa tidak lepas dari aktivitas media sosial. Maka dari itu pembelajaran yang paling cocok untuk siswa ialah sebuah pembelajaran menggunakan media yang menarik. Prof. Richardus Eko Indrajit merupakan seorang pakar teknologi di Indonesia (2019) menyatakan "Teknologi tidak akan pernah menggantikan peran guru, namun guru yang tidak memanfaatkan teknologi akan segera tergantikan, guru harus senantiasa belajar sepanjang hayatnya, karena jika seorang guru berhenti belajar, maka sejatinya dia telah berhenti menjadi guru". Teknologi pembelajaran animasi atau media audio-visual pada Generasi Z merupakan pembelajaran yang cocok dikarenakan siswa dapat berinteraksi dengan materi yang dipelajari (Pradipta et al., 2016). Teknologi yang berkaitan tentang media yang dapat diartikan sebagai sumber belajar yang secara luas ialah pembelajaran yang mengaitkan manusia, benda ataupun peristiwa yang dapat membuat siswa memperoleh suatu kemampuan dan ketrampilan (Agustien et al., 2018).

Video Animasi dapat sebagai suatu inovasi pembelajaran yang sangat menarik yang menhadirkan suasana baru dalam proses belajar-mengajar yang membuat terpacunya siswa dalam kemampuan berpikir kritis dengan disuguhkan kejadian maupun peristiwa yang dibahas (Amali et al., 2020). Peristiwa yang kompleks dapat dipahami dengan mudah dan jelas. Keuntungan lain dari penggunaan video animasi ialah menghematnya waktu saat terjadinya ketidakpahaman siswa, siswa dapat memutar kembali penjelasan secara berkalikali (Agustien et al., 2018). Belajar dengan mengaitkan lingkungan sekitar membuat tayangan video animasi lebih berkualitas karena dapat meningkatkan keterampilan proses sains serta hasil belajar (Asih, 2017).

Model APPOSITE yang di dampingi vidio animasi yang memunculkan tentang kejadian maupun peristiwa fisika lingkungan sekitar 
Model Pembelajaran APPOSITE (Application Of Step Instruction And ... 45 Aprillia Kartika Agit Wuragil, Sri Handono Budi Prastowo, dan Maryani

membuat siswa belajar dengan mudah meskipun dengan pembelajaran jarak jauh. Hal yang membuat tampak variatif dengan adanya gambar-gambar menarik yang memiliki varian warna yang mampu menjadi daya tarik sendiri untuk siswa.

Pendekatan kontekstual digunakan dalam model pembelajaran APPOSITE, pandangan teori konstruktivisme yang mendasari bahwa pentingnya pengetahuan awal dan proses instruksi secara bertahap (step Instruction). Menurut pandangan teori konstruktivisme Prastowo dalam (Kamila et al., 2020) siswa diupayakan dapat aktif dan dapat mengetahui pengetahuan secara mandiri dalam pembelajaran.

Efektivitas penelitian ini dapat diukur dari hasil belajar siswa yang menjadi sebuah pernyataan minimal terkait kemampuan siswa (Panjaitan et al., 2015). Apabila proses pembelajaran dilakukan dengan tahapan yang benar dan sesuai maka uraian penjelasan dapat mencapai tujuan dari penelitian terkait peningkatan yang terjadi pada kemampuan keterampilan berpikir tingkat tinggi siswa dengan menggunakan model APPOSITE berbantuan video animasi pada materi fluida statis.

\section{METODE/EKSPERIMEN}

Penelitian eksperimen menggunakan Pre-eksperiment design dengan menggunakan One Group Pretes-post-tes design yang merupakan jenis penelitian yang terjadi karena tidak diperlukannya kelas kontrol, dan sampel tidak dipilih secara random (Sugiyono, 2016).

$$
\mathbf{0}_{\mathbf{1}} \times \mathbf{X ~}_{2}
$$

Gambar 1. Desain Penelitian One Group Pretes-Post-tes Design

$\mathrm{O}_{1} \quad$ : Nilai Pretes (sebelum diberi perlakuan)

$X$ :Pembelajaran menggunakan model pembelajaran APPOSITE berbantuan Video Animasi

$\mathrm{O}_{2}$ : Posttes yang dihasilkan

Pengaruh dari perlakuan hasil belajar siswa $=$ (O2-O1)
Penelitian terjadi selama bulan Januari 2021. Populasi menggunakan siswa kelas XI MIPA 6 tahun ajaran 2020/2021. Penelitian memiliki sampel berjumlah 31 orang siswa di kelas eksperimen. Pengambilan data dilakukan menggunakan purposive sampling teknik ini digunakan sebagai penentuan sampel yang dikarenkana pertimbangan kondisi dan jadwal sekolah yang disesuaikan.

Penelitian ini memiliki prosedur penelitian berikut skema penelitian pada Gambar 1.

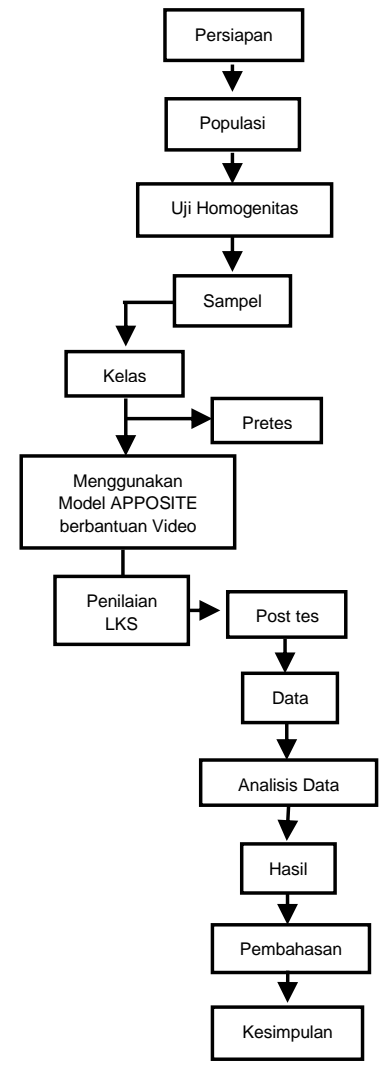

Gambar 2. Skema Penelitian

Data hasil belajar menggunakan data interval berupa tes kognitif berupa soal uraian. Pada penelitian ini juga menilai Keterampilan berpikir tingkat tinggi siswa yang menggunakan tiga aspek yaitu analisis, evaluasi dan kreasi serta level yang terdapat pada soal C4-C6. penentuan keterampilan berpikir tingkat tinggi menggunakan analisis deskriptif kuantitatif pada persamaan berikut.

$\mathrm{P}_{\mathrm{k}}=\frac{P(\text { jumlah skor yang didapat })}{N(\text { Jumlah skor maksimum })} \times 100 \%$

(Sugiyono, 2016) 
Untuk menentukan perbedaan peningkatan hasil belajar siswa, teknik analisis yang digunakan sebagai persamaan berikut.

HBS $=\frac{\text { skor yang diperoleh siswa }}{\text { skor maksimum }} \chi 100$

(Kamila, 2020)

Setelah menentukan nilai hasil belajar maka uji hipotesis dapat dilakukan dengan menggunakan data pretes dan post-tes pada kelas eksperimen. Tercapainya hasil data, analisis menggunakan teknik paired t-tes dengan menggunakan SPSS 25, uji tersebut digunakan untuk mengetahui adakah perbedaan signifikan penggunaan model pembelajaran APPOSITE berbantuan video animasi pada hasil belajar siswa setelah diberi perlakuan. Adapun pengambil keputusan dengan menggunakan uji t tentang signifikansi dari peningkatan hasil belajar sebelum perlakuan dalam penggunaan model APPOSITE berbantuan video animasi dan setelah diberi perlakuan model pembelajran APPOSITE berbantuan video animasi yang dapat dilihat dari data peningkatan nilai pretes dan post-tes kelas eksperimen yang menggunakan uji $\mathrm{n}$-gain pada persamaan berikut.

$\mathrm{N}$-gain $(g)=\left[\frac{S_{\text {post }}-S_{\text {pre }}}{S_{\text {max }}-S_{\text {pre }}}\right]$

(Hake, 1999)

(g) = peningkatan hasil belajar

$S_{\text {pre }} \quad=$ nilai pretes

$S_{\text {post }} \quad=$ nilai post-test

$S_{\text {max }}=$ skor maksimum

Hasil perhitungan n-gain dapat ditetapkan kategori skor pada Tabel 1. Berikut.

Tabel 1. Tingkat kategori n-gain

\begin{tabular}{cc}
\hline Nilai $\mathrm{N}$-gain $(\mathrm{g})$ & Kategori \\
\hline $\mathrm{N}$-gain $\geq 0,7$ & Tingi \\
$0,7>\mathrm{N}$-gain $\geq 0,3$ & Sedang \\
$\mathrm{N}$-gain $<0,3$ & Rendah \\
\hline & (Hake, 1999)
\end{tabular}

\section{HASIL DAN PEMBAHASAN}

Penelitian eksperimen pada SMA Negeri 1 Pesanggaran Kabupaten Banyuwangi pada kelas XI MIPA 6 semester genap tahun ajaran 2020/2021 dengan materi fluida statis. Jenis penelitian yang menggunakan penelitian kuantitatif dengan desain One Group PretesPost-tes Design dengan menentukan satu kelas eksperimen dengan diberikan dilakukannya pretes sebelum perlakuan dan dilakukan post-tes setelah diberikan perlakuan dengan memberikan pembelajaran menggunakan Model APPOSITE berbantuan Video Animasi, maka diperoleh hasil sebagai berikut.

\section{HASIL}

Data kemampuan berpikir tingkat tinggi diketahui dari penilaian hasil lembar kerja siswa berbentuk pretes dan posttes yang dilaksanakan secara daring menggunakan media zoom. Penilaian keterampilan berpikir tingkat tinggi dilakukan dengan berdasarkan 3 Aspek Higher Order Thingking Skill yaitu analisis, evaluasi, dan mengkreasi. Adapun data perolehan nilai setiap aspek dan rata-rata keterampilan berpikir tingkat tinggi siswa di setiap aspeknya pada kelas eksperimen dapat dilihat pada Tabel 2. Berikut.

Tabel 2. Nilai dan rata-rata setiap Aspek

\begin{tabular}{|c|c|c|c|c|}
\hline \multirow[b]{2}{*}{ No } & \multirow{2}{*}{$\begin{array}{c}\text { Aspek } \\
\text { Keterampilan } \\
\text { Berpikir } \\
\text { Tingkat } \\
\text { Tinggi }\end{array}$} & \multicolumn{2}{|c|}{ Ketercapaian \% } & \multirow{2}{*}{$\begin{array}{c}\text { Rata- } \\
\text { rata }\end{array}$} \\
\hline & & pretes & posttes & \\
\hline 1 & Menganalisis & 75,48 & 78,49 & 76,99 \\
\hline 2 & Mengevaluasi & 80,00 & 83,87 & 81,94 \\
\hline 3 & Mengkreasi & 80,65 & 86,56 & 83,60 \\
\hline & Rata-rata & 78,71 & 82,97 & 80,84 \\
\hline
\end{tabular}

Berdasarkan pada tabel 2. kita melihat hasil nilai dari tiga Aspek kemampuan berpikir Tingkat Tinggi setiap pertemuan mengalami kenaikan hasil pada aspek menganalisis, mengevaluasi, dan mengkreasi. Dalam tabel diketahui nilai terendah rata-rata presentase aspek keterampilan berpikir tingkat tinggi ialah pada aspek menganalisis sebesar $76,99 \%$, sedangkan nilai rata-rata persentase tertinggi dari aspek keterampilan berpikir tingkat tinggi ialah aspek mengkreasi sebuah pengetahuan dalam kehidupan sehari-hari pada materi pokok fluida statis ialah 83,60\%. Dari Tabel 2. diperoleh nilai rata-rata dari tiga aspek keterampilan berpikir tingkat tinggi selama 
pembelajaran fisika menggunakan model APPOSITE berbantuan Video Animasi sebesar $80,84 \%$. Hasil rata-rata presentase tersebut dapat disesuaikan dengan kriteria HOTS Tabel 2. dengan nilai rata-rata dari keterampilan berpikir tingkat tinggi masuk dalam kategori baik karena nilai rata-rata $80,84 \% \geq 76 \%$.

Hasil belajar dapat diketahui dari rangkuman hasil pretes dan post-tes dapat dilihat pada Tabel 3. sebagai berikut.

Tabel 3. Hasil Pretes dan Post-tes kelas eksperimen

\begin{tabular}{ccc}
\hline \multirow{2}{*}{ Komponen } & \multicolumn{2}{c}{ Kelas Eksperimen } \\
\cline { 2 - 3 } & Pretes & Post-tes \\
\hline Jumlah Siswa & 31 & 31 \\
& 72 & 100 \\
\hline Nilai Tertinggi & 0 & 37 \\
\hline Nilai Terendah & & 75,94
\end{tabular}

Berdasarkan Tabel 3. telah diperlihatkan rata-rata pretes dan post-tes pada kelas eksperimen yang berjumlah satu kelas. Pretes diberikan sebelum proses pembelajaran menggunakan model pembelajaran APPOSITE berbantuan Video Animasi pada kelas eksperimen yang diketahui rata-ratanya sebesar 33,55 dan rata-rata post-tes setelah diberi perlakuan dengan menggunakan model APPOSTE yang berbantuan video animasi pada proses pembelajaran didapatkan 75,94. Hasil rata-rata pretes dan pos-tes yang telah dilakukan mengalami peningkatan setelah dilakukannya sebuah perlakuan pada kelas eksperimen.

Hasil uji $N$-gain yang diperoleh dapat dilihat pada Tabel 4.

Tabel 4. Hasil N-gain Kelas Eksperimen

\begin{tabular}{ccc|c} 
& & pre_test & post_test \\
\hline \multirow{2}{*}{$\mathrm{N}$} & Valid & 31 & 31 \\
\cline { 2 - 4 } & Missing & 31 & 31 \\
\hline & Mean & 33,55 & 76,03 \\
\hline Median & 32,00 & 80,00 \\
\hline Minimum & 0 & 37 \\
\hline Maximum & 72 & 100 \\
\hline Sum & 1040 & 2357 \\
\hline
\end{tabular}

Berdasarkan Tabel 4. Diperlihatkan ratarata hasil pretes post-tes kelas eksperimen diketahui nilai $\mu_{\text {pre }}=33,55, \mu_{\text {post }}=76,03$, dan $S_{\text {maks }}=100$. Perhitungan $\mathrm{N}$-Gain sebagai berikut.

$\mathrm{N}-$ Gain $=\frac{76,03-33,55}{100-33,55}=\frac{42,48}{66,45}=0,639$

Nilai $\mathrm{N}$-Gain $=0,639$, sesuai dengan Tabel 1. Tentang rata-rata peningkatan hasil belajar siswa sebelum dan sesudah dikenai model pembelajaran APPOSITE berbantuan video animasi berada pada kategori sedang. Sehingga jika ditinjau dari peningkatan hasil belajar siswa, model pembelajaran APPOSITE berbantuan video efektif untuk meningkatkan hasil belajar siswa SMA pada materi fluida statis.

Hasil persentase keterlaksanaan pembelajaran pada tahapan model APPOSITE:

Tabel 5. Keterlaksanaan Pembelajaran Fluida Statis Pertemuan 1

\begin{tabular}{lcc}
\hline \multirow{1}{*}{ Tahapan } & \multicolumn{2}{c}{ Pertemuan 1 } \\
\cline { 2 - 3 } & Presentase & kriteria \\
\hline Invitasi & $70 \%$ & baik \\
\hline Eksplorasi & $70 \%$ & baik \\
\hline Elaborasi & $70 \%$ & baik \\
\hline $\begin{array}{l}\text { Penjelasan dan } \\
\text { solusi }\end{array}$ & $63 \%$ & $\begin{array}{c}\text { cukup } \\
\text { baik }\end{array}$ \\
\hline $\begin{array}{l}\text { Pengambilan } \\
\text { Tindakan }\end{array}$ & $72 \%$ & baik \\
\hline Evaluasi & $65 \%$ & baik \\
\hline Refleksi & $75 \%$ & baik \\
\hline
\end{tabular}

Tabel 6. Keterlaksanaan pembelajaran pertemuan 2

\begin{tabular}{lcl}
\hline \multirow{1}{*}{ Tahapan } & \multicolumn{2}{c}{ Pertemuan 2 } \\
\cline { 2 - 3 } & Persentase & kriteria \\
\hline Invitasi & $80 \%$ & baik \\
\hline Eksplorasi & $83 \%$ & $\begin{array}{l}\text { sangat } \\
\text { baik }\end{array}$ \\
\hline Elaborasi & $83 \%$ & $\begin{array}{l}\text { sangat } \\
\text { baik }\end{array}$ \\
\hline $\begin{array}{l}\text { Penjelasan dan } \\
\text { solusi }\end{array}$ & $82 \%$ & baik \\
\hline $\begin{array}{l}\text { Pengambilan } \\
\text { Tindakan }\end{array}$ & $80 \%$ & baik \\
\hline Evaluasi & $80 \%$ & baik \\
\hline Refleksi & $80 \%$ & baik \\
\hline
\end{tabular}


Tabel 7. Keterlaksanaan Pembelajaran pertemuan 3

\begin{tabular}{lcl}
\hline \multirow{2}{*}{ Tahapan } & \multicolumn{2}{c}{ Pertemuan 3 } \\
\cline { 2 - 3 } Invitasi & Presentase & kriteria \\
\hline Eksplorasi & $82 \%$ & baik \\
\hline Elaborasi & $85 \%$ & $\begin{array}{l}\text { sangat } \\
\text { baik }\end{array}$ \\
\hline $\begin{array}{l}\text { Penjelasan } \\
\text { dan solusi }\end{array}$ & $82 \%$ & $\begin{array}{l}\text { sangat } \\
\text { baik }\end{array}$ \\
\hline $\begin{array}{l}\text { Pengambilan } \\
\text { Tindakan }\end{array}$ & $85 \%$ & $\begin{array}{l}\text { Sangat } \\
\text { baik }\end{array}$ \\
\hline Evaluasi & $85 \%$ & $\begin{array}{l}\text { sangat } \\
\text { baik }\end{array}$ \\
\hline Refleksi & $82 \%$ & baik \\
\hline
\end{tabular}

Berdasarkan analisis hasil data yang terdapat pada Tabel 5 sampai dengan 7 menunjukkan bahwa seluruh langkah pembelajaran dapat dilaksanakan dengan baik oleh mahasiswa penelitian.

\section{PEMBAHASAN}

Keterlaksanaan pembelajaran dengan model APPOSITE dengan tujuh tahapan secara umum menunjukkan dapat terlaksana dengan baik. Siswa yang sangat baik berusaha melakukan refleksi diri dari hasil belajar. Pertemuan yang dilaksanakan tiga kali mengalami sebuah peningkatan sangat baik. Hal ini menunjukkan model dapat melatih siswa membentuk kemampuan keterampilan berpikir siswa khususnya pada berpikir tingkat tinggi. Berkesesuain pendapat yang dilontarkan Moreno (2010) dalam (Prastowo, 2019a) yang menunjukkan hasil belajar siswa dengan baik jika siswa mampu melakukan evaluasi diri.

Tujuan utama penelitian untuk mengetahui pengaruh model pembelajaran APPOSITE berbantuan vidio animasi dalam peningkatan hasil belajar fisika bahasan fluida statis. Berdasarkan analisis data dari hasil peningkatan belajar siswa untuk mengetahui pengaruh model pembelajaran APPOSITE berpengaruh baik dapat dianalisis dari data hasil pretes dan post-tes.

Analisis pengaruh yang signifikan data dapat diambil data nilai pretes dan post-tes dengan menggunakan uji $\mathrm{N}$-gain pada Tabel 4. Rata-rata nilai pretes dan post-tes kelas eksperimen diketahui nilainya $\mu_{\text {pre }}=33,55$, $\mu_{\text {post }}=76,03, \quad$ dan $\quad S_{\text {maks }}=100 . \quad$ Hasil perhitungan $\mathrm{N}$-gain didapatkan 0,639 . Hasil $\mathrm{N}$ gain memiliki kesesuain dengan Tabel 1. yang menyatakan perlakuan yang terjadi di kelas eksperimen dengan penggunaan model APPOSITE berbantuan video animasi memiliki kategori sedang. Sehingga adanya pengaruh peningkatan hasil belajar siswa dengan menggunakan model pembelajaran APPOSITE berbantuan video animasi efektif untuk meningkatkan hasil belajar siswa SMA pada materi fluida statis.

Adapun pengambil keputusan terhadap pengaruh model pembelajaran APPOSITE berbantuan video animasi, yang perbedaan signifikansi berpengaruh pada hasil belajar yang meningkat dikarenakan model APPOSITE berbantuan video animasi menggunakan uji ttes pada data nilai post-tes dengan bantuan program SPSS 25. Uji paired sample t-tes dapat dilakukan Jika telah memenuhi uji normalitas dan uji homogenitas maka dapat dilakukan uji t dengan metode paired sample $t$ test. Berdasarkan hasil pada tabel paired samples tes nilai signifikansi $=0,00<$ taraf signifikansi sebesar $5 \%$ yang mengartikan terdapat pengaruh signifikan penggunaan model APPOSITE berbantuan video animasi terhadap hasil belajar siswa. Hasil penelitian yang memiliki kesesuainya dengan penelitian Nur Kamila (2020) yang menyatakan pada penelitiannya terdapat pengaruh signifikan hasil belajar terutama peningkatan kognitif dengan menggunakan model pembelajaran APPOSITE pada siswa. Penelitian yang memiliki kesesuaian yang dilakukan SHB Prastowo (2019) menyatakan adanya peningkatan penguasaan konsep mahasiswa dalam penggunaan model APPOSITE dan memiliki kategori sangat baik.

Tujuan kedua penelitian dilakukan untuk mengkaji kemampuan berpikir tingkat tinggi siswa dengan menggunakan model APPOSITE berbantuan video animasi pada materi fluida statis. Berdasarkan hasil analisis keterampilan berpikir tingkat tinggi siswa selama pembelajaran menggunakan model APPOSITE berbantuan video animasi pada materi fluida statis menunjukkan bahwa keterampilan berpikir tingkat tinggi siswa dikategorikan baik. 
Hal ini telah ditunjukkan pada Tabel 2. tentang aspek rata-rata presentase berpikir tingkat tinggi tertinggi yaitu aspek mengkreasi sebesar $83,60 \%$ dan aspek rata-rata presentase terendah adalah aspek menganalisis yaitu $76,99 \%$.

Analisis keterampilan berpikir tingkat tinggi dengan bantuan video animasi memiliki kesesuaian pada penelitian yang dilakukan oleh Hamalik dalam (Agustien et al., 2018) yang menyatakan bahwa media pembelajaran pada video animasi dapat dijadikan komponen bantuan belajar yang menarik dan variatif yang dapat membantu untuk meningkatkan gairah belajar siswa dalam mengatasi keterbatasan ruang yang disebabkan oleh kendala pandemic covid 19. Pembelajaran fisika yang terdapat pada video animasi memiliki pembahasan tentang peristiwa kehidupan sehari-hari yang dapat merangsang keingintahuan siswa. Komponen media video animasi yang menampilkan sebuah peristiwa fisika yang dijelaskan menggunakan model pembelajaran APPOSITE dalam video animasi membuat siswa terpacu dalam mempelajari materi fluida statis yang dapat di temukan lingkungan rumah. Hal ini juga didukung penelitian Kamila (2020) bahwa hasil belajar pada kognitif siswa pada kelas eksperimen yang telah diberikan perlakuan dengan menggunakan model pembelajaran APPOSITE dan mengerjakan soal yang memiliki aspek $\mathrm{C} 1-\mathrm{C} 6$ mengalami peningkatan yang lebih tinggi dibandingkan pada kelas kontrol yang menggunakan model pembelajaran yang berbeda.

Tujuan ketiga mengkaji efektifitas model pembelajaran APPOSITE berbantuan video animasi untuk meningkatkan hasil belajar siswa SMA pada materi Fluida Statis didapatkan dengan cara menganalisis data nilai pretes dan post-tes menggunakan uji $\mathrm{N}$-gain. Nilai $\mathrm{N}$-gain yang didapatkan pada penelitian membuktikan terdapat peningkatan dalam hasil belajar siswa menggunakan video animasi. Pada kelas eksperimen yaitu kelas XI MIPA 6 menunjukkan nilai peningkatan pada post-tes 0,639 . Sesuai Tabel 1. maka nilai $\mathrm{N}$-gain memasuki kategori sedang sehingga model APPOSITE berbantuan video animasi memiliki keefektifan yang cukup terkait hasil belajar siswa yang meningkat pada sub materi fuida statis SMA. Analisis keefektifan penggunaan model APPOSITE berbantuan video animasi memiliki kesesuaian terhadap penilitian Nur Kamila (2020) yang menyatakan adanya peningkatan hasil belajar siswa SMA. Penelitian ini juga didukung oleh penelitian SHB Prastowo (2019) tentang model APPOSITE memiliki kategori keefektifan cukup efektif dan dengan media video animasi membuat pembelajaran online mudah untuk menjadi sarana bantuan pembelajaran siswa untuk merangsang daya pikir selama pembelajaran online yang dikarenakan pandemic covid 19. .

Keberhasilan penggunaan model APPOSITE berbantuan video animasi secara daring terdapat beberapa kendala-kendala saat dilakukannya penelitian. Salah satu kendala yang dihadapi saat melakukan tahapantahapan model APPOSITE secara maksimal dikarenakan waktu pembelajaran daring yang terlalu singkat, akan tetapi jika pengelolahan model APPOSITE dikelola secara baik maka pencapaian tujuan akan berjalan secara maksimal. Berdasarkan pembahasan yang telah di ulas menunjukkan pembelajaran fisika menggunakan model APPOSITE berbantuan video animasi dapat digunakan sebagai pilihan alternatif untuk melakukan belajar mengajar fisika dengan mengasah kemampuan berpikir tingkat tinggi siswa serta hasil belajar siswa.

\section{PENUTUP}

Kesimpulan hasil penelitian ialah adanya pengaruh signifikan meningkatkanya hasil belajar dan keterampilan berpikir tingkat tinggi siswa menggunakan model pembelajaran APPOSITE berbantuan video animasi. Hal ini didukung dengan hasil $n$-gain sebesar 0,639 yang memiliki kategori sedang.

Bagi guru penelitian ini dapat digunakan pada segala materi dalam bantuan pembelajaran konsep peningkatan hasil belajar peserta didik. Bagi peneliti yang akan melakukan penelitian, sebagai referensi penelitian lanjutan mengenai materi fisika yang memiliki pembahasan yang konseptuan dalam kehidupan sehai-hari. Penelitian yang perlu 
persiapan tentang pengelolahan yang terperinci serta pertimbangan

\section{UCAPAN TERIMAKASIH}

Terima kasih dosen pembimbing Pendidikan Fisika Universitas Jember yang membimbing proses pembuatan skripsi, serta pihak-pihak yang telah mendukung adanya penelitian, khususnya peserta didik XI MIPA 6 SMA Negeri 1 Pesanggaran Banyuwangi telah berpatisipasi dalam penelitian.

\section{REFERENSI}

Agustien, R., Umamah, N., \& Sumarno, S. (2018). Pengembangan Media Pembelajaran Video Animasi Dua Dimensi Situs Pekauman di Bondowoso Dengan Model Addie Mata Pelajaran Sejarah Kelas X IPS. Jurnal Edukasi, 5(1), 19.

https://doi.org/10.19184/jukasi.v5i1.8010

Akmala, I. N., Kusairi, S., \& Yuliati, L. (2016). Miskonsepsi Siswa SMA pada Materi Hukum Archimedes. In Pros. Semnas Pend. Sains Pascasarjana Unesa. http://lib.um.ac.id/wp-

content/uploads/2017/09/Miskonsepsi-

Siswa-SMA-Pada-Materi-Hukum-

Archimedes.pdf

Amali, L. N., Zees, N., \& Suhada, S. (2020). Motion Graphic Animation Video As Alternative Learning Media. Jambura Journal of Informatics, 2(1). https://doi.org/10.37905/jijiv2i1.4640

Asih, D. A. S. (2017). Pengaruh Penggunaan Fasilitas Belajar di Lingkungan Alam Sekitar Terhadap Keterampilan Proses Sains. Formatif: Jurnal IImiah Pendidikan MIPA, 7(1), 13-21. https://doi.org/10.30998/formatif.v7i1.133 1

Assessment, S. (2016). Penerapan Self Assessment Untuk Analisis Keterampilan Berpikir Tingkat Tinggi Siswa. Jurnal Inovasi Pendidikan Kimia, 9(1).

Hake, R. R. (1999). analyzing change/gain score. Indian University.

Hanna, D., Sutarto, \& Harijanto, A. (2016). Model Pembelajaran Tema Konsep Disertai Media Gambar Pada Pembelajaran Fisika Di Sma. Jurnal Pembelajaran Fisika, 5(1), 23-29.

Kamila, N. (2020). APLIKASI MODEL
APPOSITE (Application of Step Instruction and Elaboration) UNTUK MENINGKATKAN KETERAMPILAN PROSES SAINS DAN HASIL BELAJAR SISWA KELAS XI MATERI SUHU DAN $K A L O R$ [Universitas Jember]. https://repository.unej.ac.id/handle/12345 6789/102427

Kamila, N., Budi Prastowo, S. H., \& Nuraini, L. (2020). Penerapan Model Application of Step Instruction and Elaboration (APPOSITE) untuk Meningkatkan Hasil Belajar Kognitif Siswa SMA pada Materi Suhu dan Kalor. Journal of Natural Science and Integration, 3(2), 163. https://doi.org/10.24014/jnsi.v3i2.9348

Panjaitan, M., Febriani, Y., \& Hatika, R. G. (2015). Efektifitas Penggunaan Media Pembelajaran Fisika Berbantuan Animasi Komputer Terhadap Hasil Belajar Siswa SMA Negeri 3 Tambusai Rokan Hulu Riau. Jurnal Pendidikan Fisika.

Pradipta, P., Sutarto, S., \& Ghani, A. (2016). Media Video Kejadian Fisika di Lingkungan Disertai Besaran Fisis dalam Pembelajaran Fisika di SMA (Studi Pada Kelas X SMA Negeri 1 Muncar). Jurnal Pembelajaran Fisika, 4(4), 331-337-337.

Prastowo, S. H. B. (2019a). JPPS (Jurnal Penelitian Pendidikan Sains ) MODEL APPOSITE UNTUK MENINGKATKAN PENGUASAAN KONSEP FISIKA KINEMATIKA. 9(1).

Prastowo, S. H. B. (2019b). Model Pembeleajaran APPOSITE (Application of step instruction and Elaboration) untuk Meningkatkan Penguasaan Konsep Fisika dan Kemampuan Berpikir Kreatif Mahasiswa. Universitas Negeri Surabaya.

Romli, S., \& Agustiawan. (2020). Meningkatkan HOTS Siswa Melalui Penerapan LKS Berbasis Open-Ended Problem dalam Pembelajaran IPA. Jurnal Riset Pendidikan Fisika, 5(2), 113-118. http://journal2.um.ac.id/index.php/jrpf/arti cle/view/16560/6790

Sugiyono. (2016). Metode Penelitian Kuantitatif, Kualitatif, dan R\&D. Alfabet.

Supardi, S. U. S., Leonard, L., Suhendri, H., \& Rismurdiyati, R. (2015). Pengaruh Media Pembelajaran dan Minat Belajar Terhadap Hasil Belajar Fisika. Formatif: Jurnal IImiah Pendidikan MIPA, 2(1), 7181.

https://doi.org/10.30998/formatif.v2i1.86 